\title{
杉板から発生するセスキテルペンとオゾンとの化学反応による セスキテルペン濃度の減少とホルムアルデヒド生成の可能性に関する検討 DISCUSSION ON THE DECREASE OF SESQUI-TERPENES AND THE POSSIBILITY OF FORMALDEHYDE GENERATION CAUSED BY THE CHEMICAL REACTION BETWEEN OZONE AND SESQUI-TERPENES EMITTED FROM CEDARWOOD
}

\author{
岩下 剛*, 柴原洋人** \\ Go IWASHITA and Hiroto SHIBAHARA
}

\begin{abstract}
Full-scale chamber of test house was used to investigate emission data of sesqui-terpenes from cedarwood. This experiment involved placing samples of cedarwood and an ozone generator in one room of the test house. The sesqui-terpenes were identified. The indoor sesqui -terpenes concentration with ozone emission was much lower than that without ozone emission. It was found that the higher the indoor ozone concentration, the lower the sesqui-terpenes concentration. The sesqui-terpenes might have been consumed by the reaction with ozone during the experiment. The concentrations of formaldehyde ( $\mathrm{HCHO}$ ) were not changed regardless of the change of ozone concentration. $\mathrm{HCHO}$ is not expected to be formed by the reaction between ozone and the major sesqui-terpenes emitted from cedarwood.
\end{abstract}

\section{Keywords: Cedarwood, Sesqui-terpenes, Formaldehyde, Ozone, Chemical reaction}

杉板、セスキテルペン、ホルムアルデヒド、オゾン、化学反応

\section{1 はじめに}

接着剂、塗料などから放たれる VOC（揮発性有機化合物）が、シ ックハウス、シックビル問題の主原因と考えられるようになり、そ の対策の一つとして、無脈の木材を内装材として用いる住宅が注目 されている。たとえば、無垢の木材が床材、壁材、天井材として用 いられた住宅では、トルエン、キシレンのような芳香族炭化水素 VOC の発生は少ない一方で、Pinene<alpha->、Limonene のようなテルペン の発生が多くなることが予想される。厚生労働省のシックハウス問 題に関する検討会 ${ }^{1)}$ により、TVOC（全揮発性有機化合物）濃度は $400 \mu \mathrm{g} / \mathrm{m}^{3}$ 以下という暫定目標値が策定されているが、筆者らの実測 では、内装材に杉板が使用されている住宅において、新築時にテル ペンの濃度が TVOC 暫定目標值を大きく超えている結果 ${ }^{2)}$ が得られ た。このようなテルペンの人体への健康影響について考察した研究 は少なく、明らかでない部分が多い。一方、室内で発生するVOC と、 換気によってもたらされる外気の中に含まれるオゾンとの反応とい う視点で考えると、テルペンとオゾンとの反応で、別の化学物質が 生成されることが考えられ、それが有害な物質である場合、問題が 生じる。室内 VOC とオゾンとの反応については、近年、様々な報告 がされており、Wolkoff らはテルペンとオゾンとの反応により、刺激
性の高い物質が生成されることを報告している ${ }^{3)}$ 。Wolkoff らはマウ スを用いた生物実験において、4-6 ppm のオソンに、60-80 ppm およ び 500 ppm のテルペン（Isoprere, Pinene <alpha->, Limonene）を混合 させ、刺激物質の生成を確認している。このような高浱度は、マウ スと人間の感度の違いを考慮して設定されたとのことであるが、実 際の室内で生じる現象を調查するには、より現実的なテルペン濃度 およびオゾン濃度を設定することが重要と考えられる。Weschler \& Shields はテルペンとオソンとの反応により微粒子濃度が上昇するこ とを報告している ${ }^{4)}$ 。実際のオフィスを想定して実験を行なった彼ら は、オゾン発生器により $230-330 \mathrm{ppb}$ の室内オゾン涶度を放出し、ま た、容器から Limonene, Terpinene<alpha->を発生させた。このオゾン

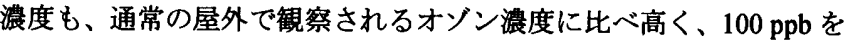
下回るオソンン濃度での条件を設定することが、より現実的と思われ る。Grosjean らは pinene<beta->、 Limonene の 2 つのテルペン及びセ スキテルペン注 1) である Caryophyllen<trans->とオゾンとの反応で、ホ ルムアルデヒドが生成されたことを実験によって確認している ${ }^{5}$ 。彼 らは 0.07-0.10 ppm のオゾンに対して、1.0 ppmの pinene<beta->、1.2 ppm の Limonene、0.2-0.5 ppm の Caryophyllen <trans->をそれぞれ容積 $3.5 \mathrm{~m}^{3}$ のチャンバーにおいて反応させた。その結果、 pinene <beta->の
* 鹿児島大学工学部建築学科 助教授 $\cdot$ 工博

**高砂熱学工業(侏) 工修 (当時 鹿児島大学大学院)
Assoc. Prof., Dept. of Architecture, Faculty of Engineering, Kagoshima University, Dr. Eng.

Takasago Thermal Engineering, M. Eng.

(Formerly Graduate Student, Kagoshima University) 
場合は 19-26 ppb のホルムアルデヒドが生成され、Limonene は 6-9 ppb の、Caryophyllen < trans->は 2-8 ppb のホルムアルデヒドが生成さ れたとしている。Grosjean らが述べているように5)、セスキテルペン とオゾンとの反応を調査した例は、ほとんどなく、彼らも Caryophyllen <trans->を扱っているのみである。日本の住宅において 用いられることが多い杉板からは多種のセスキテルペンが発生する と考えられ、これらとオゾンとの反応を考察することは重要である。 そこで、現実に室内で起こりうるオソン濃度と、木造住宅室内で検 出されるセスキテルペンの濃度レベルを実験条件として設定した場 合、オゾン/セスキテルペン反応はどのような量で生じるのか、そし て、仮に両者の反忘によりホルムアルデヒドが生成されるのであれ ば、どの程度の濃度レベルになるのかを調查することを計画した。 本研究では、無垢の木材を内装材として用いた木造住宅室内におけ る環境を想定しているため、セスキテルペンとしては、杉板から実 際に発生されるものを用い、また、オソン濃度は、消系目的で室内 で用いるレベルの濃度を設定した。また、セスキテルペンとオゾン との反応により、仮にホルムアルデヒドが生成されるとした場合、 その濃度が居住環境レベルでどの程度の重要性を持つのかを確認す るために、実際の居住空間で調査することを試みた。

\section{2 実験方法}

\section{1 実験箇所}

実験は鹿児島大学構内の実験住宅 ${ }^{6)}$ にて行った。図 1 に実験住宅 の平面図を示すが、本実験では室 1 及び室 2 を実験室とした。実験 住宅の各室は $15 \mathrm{~m}^{3} / \mathrm{h}$ の換気量の機械換気がされており、室温は $25^{\circ} \mathrm{C}$ になるようにエアコンで調節を行った。室 1 、室 2 の各室は、床面積 が $9.9 \mathrm{~m}^{2}$ 、天井高が $2.5 \mathrm{~m}$ であり、空の外側のロールブラインド及び 室内側の遮光カーテンを降ろすことで、室内への日射の影響が少な くなるようにした。実験住宅の室 1 のみに、市販の杉板 (厚さ $15 \mathrm{~mm}$ ) を床に敷設した。杉板の曝露面積は $5.7 \mathrm{~m}^{2}$ であり、ローディングフ アクターは $0.23 \mathrm{~m}^{2} / \mathrm{m}^{3}$ である。ローディングファクターは、床面の大 部分が無垢の杉板で構成されていることを想定して決めた。

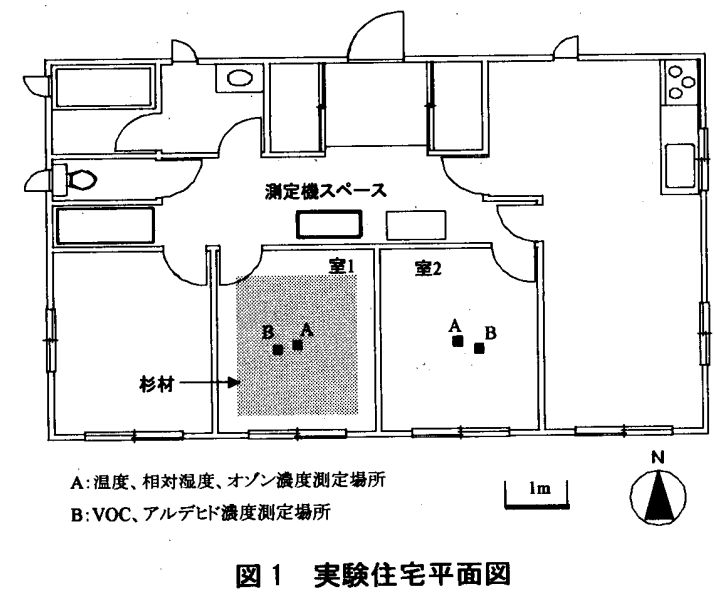

\section{2 実験手順}

実験手順の図を図 2 に示す。本実験では、室 1 のみに供試材であ る杉板を設置し、室 2 は、供試材を設置しない対照室である。室 1 に杉板を設置した時間を $\mathrm{t}=0$ とした（tの単位は時間[hour])。この杉
板は、実験開始の 5 日前に購入し、テフロンバッグに入れて、倉庫 に保管してあったものを $\mathrm{t}=0$ の直前に実験住宅に搬入し、開封、設置 した。オソンについては消臭目的で室内で用いられるオゾン発生器 （オソンドーム、株式会社 田窪工業所）によって、室 1 、室 2 の両 室において、杉板設置から 360 時間後（t=360）にLow モードで発生 させ、480 時間後にHigh モードで発生させた。

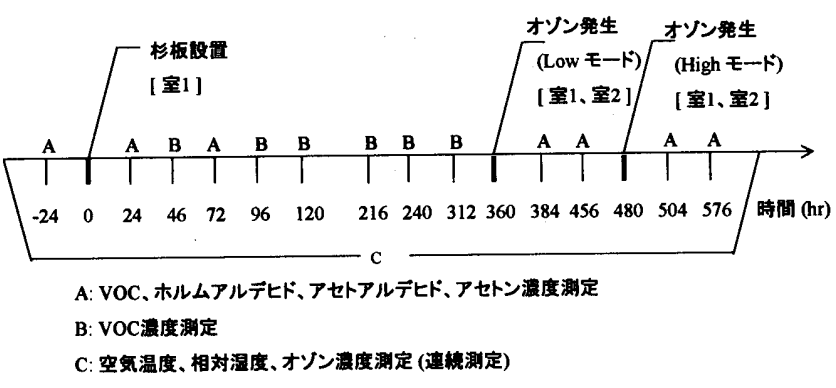

図 2 実験手順

\section{3 測定項目}

測定項目及び測定機器を表 1 に示す。測定項目は、室内空気温度、 相対湿度、オソン筤度、VOC 濃度、ホルムアルデヒド濃度、アセト アルデヒド濃度、アセトン濃度である。空気温度・相対湿度、オソ ン濃度は連続的に測定を行った。上記の測定項目は、室 1 、室 2 の室 内及び外気で測定を行った。また、オゾン濃度については、室内中 央の測定点だけでなく、機械換気の吹出口においても測定を行った。 VOC 濃度は測定筒所の空気を固体捕集管（テナックス TA）に 50 $\mathrm{mL} / \mathrm{min}$ の流量で 20 分、計 1 リットルをアクティブ吸引してサンプ リングしたのち、加熱脱着装置で加熱、コールドトラップし、ガス クロマトグラフ/質量分析（GC/MS）装置にて分析、定量を行った。 また、換気量については、各室にトレーサーガスを定量発生させる ことによって求めた。トレーサーガスである $\mathrm{SF}_{6}$ の潾度測定には、光 音響法マルチガスモニターを用いた。

表 1 測定項目及ひ測定機器

\begin{tabular}{|c|c|c|}
\hline \multicolumn{2}{|l|}{ 測定項目 } & 測定機器 \\
\hline \multicolumn{2}{|c|}{ 温度・相対湿度 } & おんどとり RH-TR72S（T\&D 社） \\
\hline \multicolumn{2}{|l|}{ オソン濃度 } & 柴外線吸収式オソンン濃度計（ダ价ック社） \\
\hline \multicolumn{2}{|l|}{ VOC 濃度 } & 吸着管: TENAX TA / 分析装置: GC/MS \\
\hline \multicolumn{2}{|c|}{$\begin{array}{l}\text { 杖アルデヒド・アセトアル } \\
\text { デヒド・アセけ濃度 }\end{array}$} & $\begin{array}{l}\text { 吸着管 : DNPH カートリッ゙ } \\
\text { 分析装置 : HPLC }\end{array}$ \\
\hline \multicolumn{2}{|l|}{$\mathrm{SF}_{6}$ 濃度 } & $\begin{array}{l}\text { 光音響法マルチガ スモニ多（B\&K 社, 1302） } \\
\text { マルチボ イントサフプラー\&ドーザー（B\&K 社, 1303) }\end{array}$ \\
\hline \multicolumn{3}{|c|}{ 表 2 ガスクロマトグラフ分析条件 } \\
\hline カラム & SPB1 & $5.00 \mu \mathrm{m} \times 60 \mathrm{~m} \times 0.32 \mathrm{~mm}$ \\
\hline 昇温条件 & $50^{\circ} \mathrm{C}$ 力 & ら $10^{\circ} \mathrm{C} /$ 分で $260^{\circ} \mathrm{C}$ まで昇温 \\
\hline
\end{tabular}

ガスクロマトグラフ (GC) の分析条件を表 2 に示す。ホルムアル デヒド、アセトアルデヒド、アセトン濃度はオソンンクラバーを取 り付けた DNPHカートリッジに約 15 リットルの空気をアクティブ吸 引してサンプリングした後、アセトニトリルを溶媒として抽出し、 高速液体クロマトグラフにて分析を行った。 


\section{3 実験結果}

\section{1 温度・湿度及ひ換気量}

実験期間における温度・湿度の平均值及びトレーサーガス定量発 生法で求めた各室の換気量（当該室以外の空間から侵入する空気量） を表 3 に示す。室 1 でトレーサーガスを発生させた場合、定常濃度 の約 $6 \%$ の濃度が室 2 で検出され、室間換気量の存在が考えられたが、 室内空気質に有意な影響を与えるほど多量ではないとみなし、本研 究では室間換気量の影響を考慮しなかった。室 1 にのみ供試材を設 置し、他室からの供試材由来の化学物質の発生が無いことも、室間 換気量の影響を考虑しなかった理由の一つである。しかし、複数の 室に異なる供試材を設置し、各室の化学物質の濃度変化や発生量を 算定する場合には、室間換気量の影響を考虑することが重要である。

表 3 実験中の温度・相対湿度

\begin{tabular}{|l|c|c|c|}
\hline & 空気温度 $\left({ }^{\circ} \mathrm{C}\right)$ & 相対湿度 $(\%)$ & 換気量 $\left(\mathrm{m}^{3} / \mathrm{h}\right)$ \\
\hline 室 1 & $25.0 \pm 0.7^{*}$ & $52.6 \pm 4.0$ & 15.7 \\
\hline 室 2 & $25.6 \pm 1.0$ & $48.9 \pm 2.9$ & 14.3 \\
\hline 外気 & $20.9 \pm 3.9$ & $70.0 \pm 18.7$ & \\
\hline
\end{tabular}

*平均値士標準偏差

\section{2 オソン濃度}

オゾン濃度は室 1 、室 2、外気の濃度を実験期間中連続的に観測し た。表 4 に室 1 内、室 1 吹出口及び外気における、オソン発生条件 別の各状態下におけるオゾン濃度の平均值を示す。オゾン発生の無 い、通常の状態 $(-24 \leqq \mathrm{t}<360)$ では、室内のオゾン濃度は外気の約 1/10 となっている。また、オゾン発生器をLow モードで稼動すると、 室内オゾン濃度は約 6ppb に、High モードで稼動すると、約 30ppb に なっている。

表 4 各条件下の平均オソン濃度 (ppb)

\begin{tabular}{|c|c|c|c|c|}
\hline \multicolumn{2}{|l|}{$\begin{array}{l}\text { オソンン発生状態 } \\
\text { (期間) }\end{array}$} & $\begin{array}{l}\text { 室 } 1 ・ \\
\text { 室内 }\end{array}$ & $\begin{array}{l}\text { 室 1・ } \\
\text { 吹出口 }\end{array}$ & 外気 \\
\hline \multirow{4}{*}{$\begin{array}{l}\text { オゾン発生無し } \\
(-24 \leqq t<360)\end{array}$} & $-24 \leqq t<120$ & $1.3 \pm 0.7^{*}$ & $2.4 \pm 2.4$ & $13.1 \pm 14.3$ \\
\hline & $120 \leqq \mathrm{t}<240$ & $1.0 \pm 0.4$ & $1.5 \pm 1.2$ & $9.9 \pm 13.0$ \\
\hline & $240 \leqq t<360$ & $1.0 \pm 0.1$ & $2.3 \pm 1.5$ & $11.9 \pm 11.7$ \\
\hline & $-24 \leqq \mathrm{t}<360$ & $1.1 \pm 0.5$ & $2.1 \pm 1.9$ & $11.8 \pm 13.1$ \\
\hline \multicolumn{2}{|c|}{$\begin{array}{l}\text { オゾン発生 Low モード } \\
(360 \leqq \mathrm{t}<480)\end{array}$} & $5.8 \pm 2.0$ & $3.0 \pm 2.0$ & $8.8 \pm 10.0$ \\
\hline \multicolumn{2}{|c|}{$\begin{array}{l}\text { オゾン発生 High モード } \\
(480 \leqq \mathrm{t}<580)\end{array}$} & $30.6 \pm 4.6$ & $3.6 \pm 1.9$ & $11.2 \pm 9.0$ \\
\hline
\end{tabular}

図 3 に、杉板設置 3 日目（t元72）の日のオゾン濃度経時変化を示 す。外気オゾン濃度は昼間に上昇する傾向があり、機械換気の吹出 口における潾度は、それにつれ昼間に上昇している。一方、室内オ ゾン濃度は一日を通して大きな変動が無い。なお、外気取り入れ口 から室内吹出し口までのダクト長さは直線距離で、10〜14m である。

\section{3 ホルムアルデヒド、アセトアルデヒド、アセトン濃度}

HPLC（高速液体クロマトグラフ）法による、室 1 及び室 2 のホル ムアルデヒド、アセトアルデヒド、アセトン濃度の経時変化を図 4
に示す。室 1 におけるホルムアルデヒド、アセトアルデヒド、アセ トンは、Low モードでのオゾン発生を行なった前後（ $t \fallingdotseq 360 ）$ の濃度 上昇はみられない。また、High モードでの発生を行なった前後（t †480）の室 1 における濃度上昇もみられない。室 1 と室 2 のホルム アルデヒド、アセトアルデヒド、アセトンの濃度を比較すると、オ ゾンの Low モード発生及び High モード発生にかかわらず、室 1 と室 2 の濃度は、ほぼ同濃度である。よって、オソンと杉板から発生する VOC との反応により、ホルムアルデヒド、アセトアルデヒド、アセ トン濃度が上昇する現象は生じなかったと考えられる。

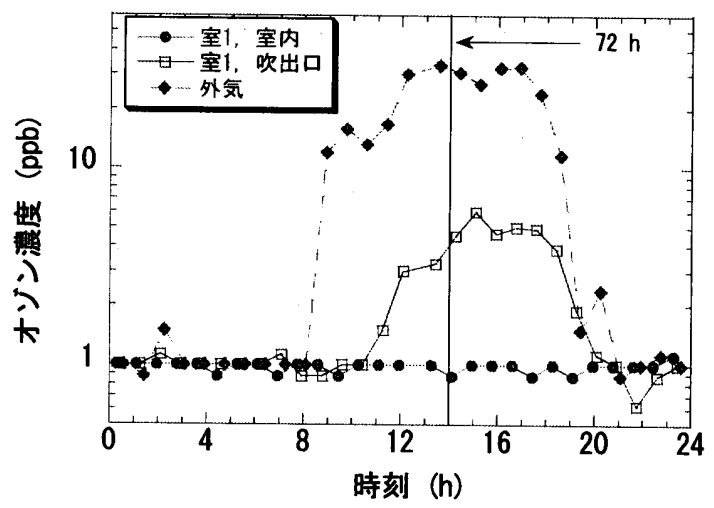

図 $3 t=72$ [hour]付近のオゾン濃度

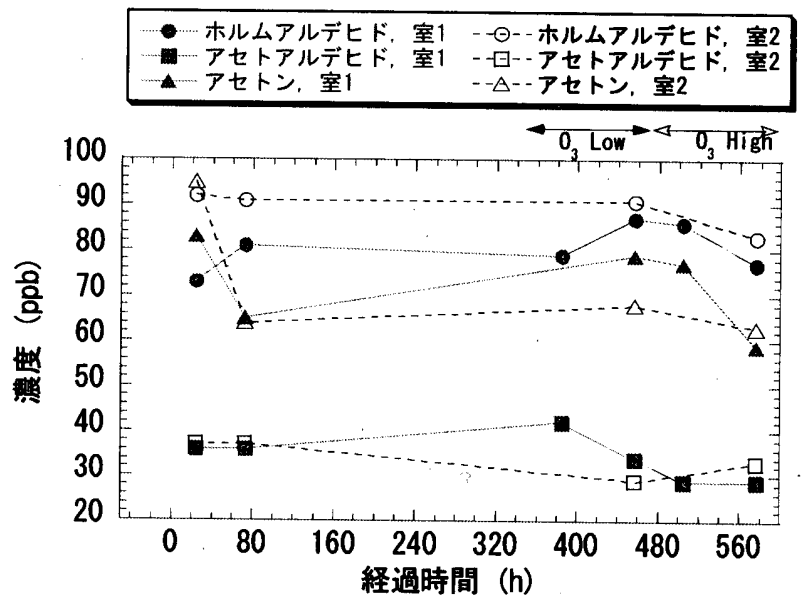

図 4 ホルムアルデヒド、アセトアルデヒド、アセトン濃度

\section{4 VOC 濃度}

表 5 に、同定・定量を行なった VOC について、杉板設置よりも 24 時間前 $(\mathrm{t}=-24)$ の時の濃度及び、杉板設置 24 時間後 $(\mathrm{t}=24)$ の時の濃度 を示す。同定・定量を行なったテルペンである、Pinene<alpha->, Pinene <beta->, Limonene は、杉板設置後に濃度が大きく上昇していないた め、設置した杉板から発生したものではなく、実験住宅躯体からの 発生と考えられる。

図 5 に、杉板を室 1 に設置してから 24 時間後の室 1 内空気のクロ マトグラムを示す。Pinene < alpha->, Pinene <beta->, Limonene が保持 時間 10〜12 分近辺の小さなピーク（添字：a，b，c）であるのに対 し、保持時間 20 分付近にみられる VOC のピークが非常に大きいこ とがわかる。これらのピークは、杉板設置前にはみられなかったた め、杉板から発生する物質であると考えられる。 
表 $5 \mathrm{t}=-24 、 \mathrm{t}=24$ における VOC 濃度 $\left(\mu \mathrm{g} / \mathrm{m}^{3}\right)$

\begin{tabular}{|c|c|c|c|c|c|c|}
\hline \multirow[b]{2}{*}{ VOC } & \multicolumn{3}{|c|}{$t=-24$} & \multicolumn{3}{|c|}{$t=24$} \\
\hline & 室 1 & 室 2 & 外気 & 室 1 & 室 2 & 外気 \\
\hline butanol & 18.6 & \begin{tabular}{|l|}
23.6 \\
\end{tabular} & \begin{tabular}{|l|}
$<1.0$ \\
\end{tabular} & \begin{tabular}{|r|}
25.3 \\
\end{tabular} & \begin{tabular}{|l|}
17.6 \\
\end{tabular} & $<1.0$ \\
\hline benzene & $<1.0$ & $<1.0$ & 3.7 & $<1.0$ & $<1.0$ & 7.5 \\
\hline heptane & 1.9 & $<1.0$ & $<1.0$ & 0.6 & $<1.0$ & 3.0 \\
\hline MIB & 1.6 & 2.3 & $<1.0$ & 2.2 & 1.1 & 2.4 \\
\hline toluene & 32.6 & 25.6 & 7.3 & 27.9 & 28.0 & 18.7 \\
\hline ethylbenzene & 7.3 & 7.8 & 1.4 & 5.1 & 6.0 & 4.0 \\
\hline $\mathrm{p}, \mathrm{m}$-xylene & 4.2 & 5.8 & 0.9 & 3.5 & 4.1 & 3.2 \\
\hline styrene & 9.6 & 10.2 & $<1.0$ & 10.1 & 7.3 & $<1.0$ \\
\hline 0 -xylene & 10.2 & 9.5 & 1.0 & 11.9 & 7.6 & 2.6 \\
\hline nonane & 3.4 & 2.2 & 0.6 & 3.0 & 1.8 & 0.5 \\
\hline pinene $<$ alpha- $>$ & 8.6 & 7.9 & $<1.0$ & 8.9 & 9.1 & $<1.0$ \\
\hline $1,3,5-\mathrm{TMB}$ & 1.1 & $<1.0$ & $<1.0$ & $<1.0$ & 1.1 & $<1.0$ \\
\hline pinene $<$ beta- $>$ & 3.3 & 4.1 & $<1.0$ & 1.7 & 2.0 & $<1.0$ \\
\hline $1,2,4-\mathrm{TMB}$ & 8.4 & 8.2 & 3.1 & 8.6 & 6.9 & 6.4 \\
\hline 1,4-dichlorobenzene & 1.1 & 1.7 & $<1.0$ & 1.0 & 1.1 & $<1.0$ \\
\hline decane & 3.6 & 4.2 & $<1.0$ & 3.1 & 3.0 & 2.2 \\
\hline limonene & 12.8 & 12.3 & $<1.0$ & 10.8 & 11.2 & $<1.0$ \\
\hline nonanal & 7.5 & 19.6 & 3.8 & 6.8 & 4.5 & 4.7 \\
\hline undecane & 2.4 & 2.0 & $<1.0$ & 2.2 & 1.7 & $<1.0$ \\
\hline decanal & 5.9 & 5.0 & 5.9 & 4.1 & 3.9 & 7.7 \\
\hline dodecane & 1.0 & 1.3 & $<1.0$ & 1.1 & 1.2 & 1.8 \\
\hline tridecane & 1.1 & 1.0 & $<1.0$ & 1.2 & 1.0 & $<1.0$ \\
\hline tetradecane & 1.6 & 2.3 & $<1.0$ & 3.4 & 1.6 & $<1.0$ \\
\hline
\end{tabular}

NIST ライブラリーの検索によって、保持時間 20 分付近のピーク 物質の候補として、セスキテルペンが挙がったが、同定はできなか った。そこで、Adams の同定手法 ${ }^{7)}$ に従い、表 6 に示す GC 分析条 件で、これらセスキテルペンの同定を行なった。同定は保持時間、 文献 7)に揭載されているMass スペクトルとの比較、及び Kovats Index 注2)を用いて行なった。図 5 中の付表に、同定結果を示す。付表をみ ると、最も大きなピーク番号 7 は Cadinene $<$ delta->、次に大きいピー ク番号 6 は Muurolene<alpha->であることがわかる。

\section{表 6 セスキテルペン同定用のガスクロマトグラフ分析条件}

\begin{tabular}{|l|l|}
\hline カラム & DB5 $\quad 0.25 \mu \mathrm{m} \times 30 \mathrm{~m} \times 0.25 \mathrm{~mm}$ \\
\hline 昇温条件 & $60^{\circ} \mathrm{C}$ から $3^{\circ} \mathrm{C} /$ 分で $246^{\circ} \mathrm{C}$ ま昇温 \\
\hline
\end{tabular}

表 7 は、図 5 で添字番号 1 10 で示したセスキテルペンの、杉板 設置 24 時間前の濃度及び、杉板設置 24 時間後の濃度である。これ ら、セスキテルペンの濃度は全て、トルエン換算の濃度である。セ
スキテルペンと考えられる VOC（ピーク番号 1～10）の濃度の合計 （以降、総セスキテルペン濃度と呼ぶ）のうち、ピーク番号 6,7 ，の セスキテルペンの占める割合は、杉板設置以降（〉0) は 80〜95\%で ある。ピーク番号 6,7 のセスキテルペンは、著者らが以前、杉板を 内装材として用いた住宅における空気質害測においても、最も高い トルエン等価濃度を示していたセスキテルペンである ${ }^{2), 8) 。 ~}$

表 $7 \mathrm{t}=-24 \mathrm{~h} 、 \mathrm{t}=24 \mathrm{~h}$ におけるセスキテルペン濃度 $\left(\mu \mathrm{g} / \mathrm{m}^{3}\right)$

\begin{tabular}{|c|c|c|c|c|}
\hline & \multicolumn{2}{|c|}{$t=-24$} & \multicolumn{2}{|c|}{$t=24$} \\
\hline $\begin{array}{l}\text { No.* } \\
\text { VOC }\end{array}$ & \begin{tabular}{|l|l|l|l|} 
室 1 \\
\end{tabular} & 室 2 & 室 1 & 室 2 \\
\hline \begin{tabular}{l|l} 
Cubebene <alpha- $>$ \\
\end{tabular} & \begin{tabular}{|l|}
$<1.0$ \\
\end{tabular} & $<1.0$ & 16.7 & $<1.0$ \\
\hline 2 Copaene <alpha-> & $<1.0$ & $<1.0$ & 14.8 & 1.4 \\
\hline 3 Caryophyllene $<(E)->$ & $<1.0$ & $<1.0$ & 38.2 & 3.4 \\
\hline 4 Humulebe <alpha-> & $<1.0$ & $<1.0$ & 17.5 & $<1.0$ \\
\hline 5 Cadia-1(6), 4-diene < trans-> & $<1.0$ & $<1.0$ & 56.3 & 1.3 \\
\hline \begin{tabular}{|l|l|}
6 & Muurolene <alpha-> \\
\end{tabular} & $<1.0$ & $<1.0$ & 133.7 & 12.6 \\
\hline $\begin{array}{ll}7 & \text { Cadinene }<\text { delta- }> \\
\end{array}$ & $<1.0$ & $<1.0$ & 457.3 & 26.8 \\
\hline 8 Cadia-1(2), 4-diene < trans-> & $<1.0$ & $<1.0$ & 16.7 & 1.5 \\
\hline 9 Cubenol <1-epi-> & $<1.0$ & $<1.0$ & 27.0 & $<1.0$ \\
\hline $\begin{array}{lll}10 & \text { Cubenol } \\
\end{array}$ & $<1.0$ & $<1.0$ & 20.2 & $<1.0$ \\
\hline
\end{tabular}

* : 図 5 中のピークの番号

総セスキテルペン濃度の八割以上を占めていた、ピーク番号 6 と 7 のセスキテルペンの室 1 におけるトルエン等価濃度の合計值(以下、 代表セスキテルペン濃度と呼ぶ）の経時変化を、オジン濃度ととも に図 6 に示す。杉板設置後、代表セスキテルペン濃度は急上昇し、 96 時間後までは、代表セスキテルペン濃度だけで、TVOC 暫定目標 值の $400 \mu \mathrm{g} / \mathrm{m}^{3}$ を超えている。しかし、その後、减衰し、120 時間後 には $330 \mu \mathrm{g} / \mathrm{m}^{3}$ 程度になり、ほぼ定常に達する。360 時間後 $(\mathrm{t}=360)$ にはオゾン発生器が Low モードで稼動されるため、オゾン濃度が 6 ppb 程度に上昇するが、それとともに代表セスキテルペン濃度が 150 $\mu \mathrm{g} / \mathrm{m}^{3}$ 程度に低下している。その後、 $\mathrm{t}=480$ 以降、High モードでオ ゾン発生器が稼動され、室内オソン濃度が $30 \mathrm{ppb}$ を越えるようにな るが、この期間、代表セスキテルペン濃度は $50 \mu \mathrm{g} / \mathrm{m}^{3}$ 程度まで下が っていく。オソン濃度の上昇により、代表セスキテルペン濃度が急 激に減少していることから、番号 6 と 7 のセスキテルペンが、オゾ ンとの反応により消費されたことが考えられる。一方、図 4 に示し たように、実験中のホルムアルデヒド濃度には、オゾン発生による 大きな変動は無く、セスキテルペンとオゾンとの反応により、セス

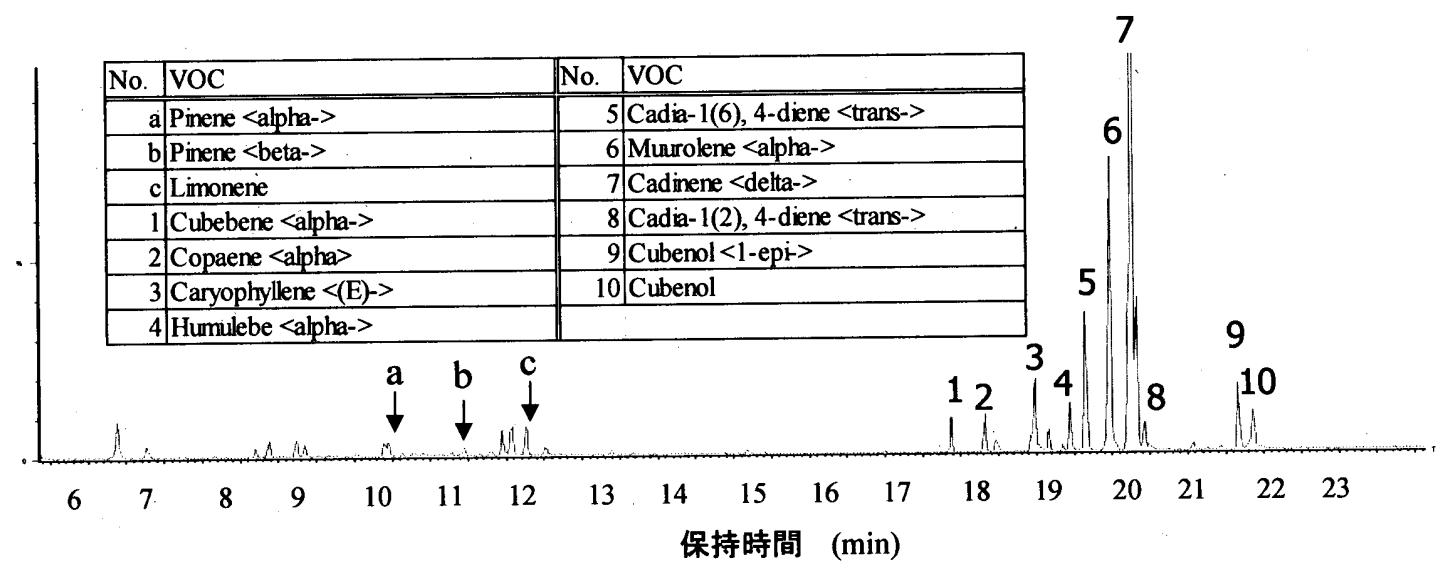

図 $5 \mathrm{t}=24 \mathrm{~h}$ における室 1 空気のクロマトグラム（欄内に付表） 
キテルペンは消費されたと推察できるが、それによってホルムアル デヒドが室内濃度レベルを有意に上昇させるほど多量に生成された とは考えにくい。

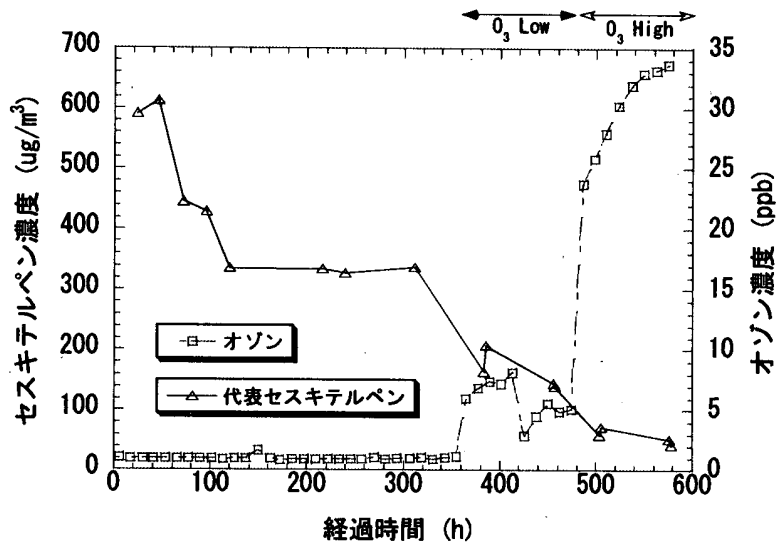

図 6 代表セスキテルペン濃度及びオソン濃度の経時変化

\section{4 考察}

図 6 に示されているように、オゾンの発生によりセスキテルペン 濃度が诚少する結果が得られたが、図 4 ではオソン発生によるホル ムアルデヒド濃度上昇はみられなかった。そこで、発生したセスキ テルペンの化学構造から、オソンとの反応によるホルムアルデヒド、 アセトアルデヒド、アセトンの発生の可能性について検討すること にする。セスキテルペンとオゾンとの反応は、セスキテルペンの二 重結合を、オソンが開裂することによって進行する。二重結合炭素 原子の 1 個が 2 個の水素原子と結合しているならば、オゾン分解の 生成物はホルムアルデヒド（メタナール）になるが、2 個の水素原 子と結合していない場合は、ホルムアルデヒドは生成されない9)。な お、二重結合炭素原子にアルキル基と水素原子が結合しているなら ば、生成物はアルデヒドになる（図 7 参照)。<smiles>[R]C=CC=O</smiles>

図 7 オソン分解の生成物

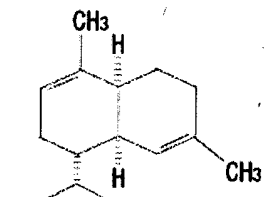<smiles>CC1=CCC(C)C2C1CC=C(C)C2C(C)C</smiles><smiles>C=C1CCC[C@H](C)[C@H]2CC(C)(C)CC[C@H]12</smiles>

Murolene 〈alpha-> Cadinen $\langle$ delta -$\rangle$ Caryophyllene $\langle(E)-\rangle$

図 8 ピーク番号 6 (左) と7 (中央) 及びピーク番号 3 (右) のセスキテルペンの化学構造

杉板から発生したセスキテルペンのうち、大部分を占めていたピ 一ク番号 6 と 7 のセスキテルペンの化学構造を図 8 に示す。どちら のセスキテルペンも二重結合炭素原子の 1 個が 2 個の水素原子と結 合していない（C=C の二重結合に $\mathrm{H}_{2}$ がついていない）ため、オゾ ンによる開裂があっても、ホルムアルデヒドは生成されないと考え
られる。同様に二重結合炭素原子にメチル基 $\left(\mathrm{CH}_{3}\right)$ と水素原子が 結合している部分もみられないため、アセトアルデヒドも生成され ず、また、二重結合炭素原子に二個のメチル基が結合している部分 もみられないため、アセトン生成もないと考えられる。一方、図 5 に示したピーク番号 1〜10 のセスキテルペンのうち、C=C の二重結 合に $\mathrm{H}_{2}$ がついている物質は、ピーク番号 3 の Caryophyllene <(E)-> のみであった。このセスキテルペンの化学構造を図 8 の右端に示す。 ピーク番号 3 のセスキテルペンはオソン開裂により、ホルムアルデ ヒドを生成する可能性があるが、Caryophyllene $<(\mathrm{E})->$ 杉板からの発 生量が多くはないため、有意なホルムアルデヒド濃度の上昇には至 らなかったのではないかと考えられる。

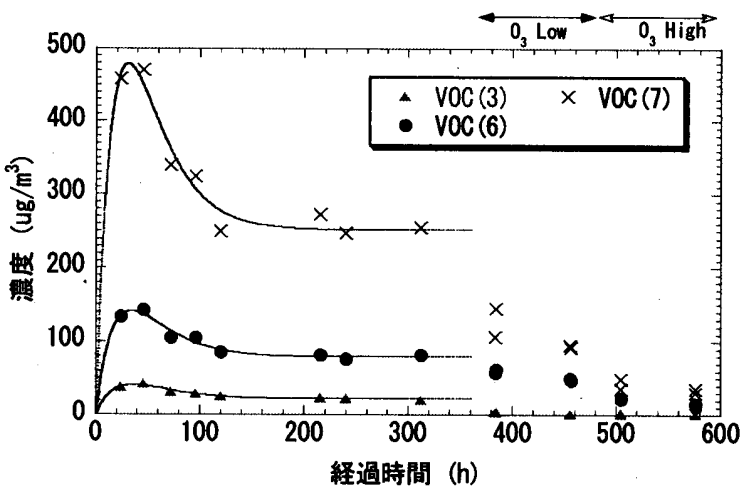

図 9 ピーク番号 3, 6,7 のセスキテルペンの濃度経時変化

[ $\operatorname{VOC}(3)$ : Caryophyllene <(E)->, VOC(6): Muurolene <alpha->, VOC(7): Cadinene $<$ delta- $>$ ]

図 9 に、室 1 における、ピーク番号 3、6、7 のセスキテルペンの トルエン等価濃度の経時変化を示す。図中の回帰曲線は、式（1）に 示す Colombo らの提案した二重指数减衰モデル ${ }^{8)}$ を、360 時間まで の濃度データに非線形回帰によってあてはめた曲線である。非線形 回帰によって求めた各セスキテルペンの定常濃度から、放散速度 (ト ルエン濃度等価）を求めると、ピーク番号 3 の Caryophyllene <(E)-> が $58.1 \mu \mathrm{g} / \mathrm{m}^{2} \cdot \mathrm{h}$ 、番号 6 の Muurolene <alpha->が $209.2 \mu \mathrm{g} / \mathrm{m}^{2} \cdot \mathrm{h}$ 、 番号 7 の Cadinene<delta->が $664.6 \mu \mathrm{g} / \mathrm{m}^{2} \cdot \mathrm{h}$ であった。

$$
\text { Conc }=K_{1} \times\left[1-\exp \left(-K_{2} \times t\right)\right]-K_{3} \times\left[1-\exp \left(-K_{4} \times t\right)\right]
$$

ここで、Conc. : 濃度 $\left[\mu \mathrm{g} / \mathrm{m}^{3}\right] \quad t$ : 時間 [hour]

$$
K_{l}, K_{3}: \text { 線形定数 }\left[\mu \mathrm{g} / \mathrm{m}^{3}\right] \quad K_{2}, K_{4} \text { : 時定数 }\left[\mathrm{h}^{-1}\right]
$$

オゾン発生を強制的に行なわず、通常の室内濃度レベルのオゾン 状態であれば、上記の放散速度により、セスキテルペンの定常湦度 が得られるが、本実験のようにオゾンを強制的に付加することによ って、セスキテルペンはオゾン反応により消失し、濃度は低下する。 そこで、本実験におけるセスキテルペンのオゾン反応による消失速 度を式(2)の物質平衡式を用いて試算した。

$$
\frac{d C}{d t}=N \cdot C_{0}+S E R \cdot \frac{A}{V}-N \cdot C-G \cdot C
$$

ここで、

$C:$ 室内セスキテルペン濃度 $\left[\mu \mathrm{g} / \mathrm{m}^{3}\right]$

$N:$ 換気回数 $\left[\mathrm{h}^{-1}\right]$

$C_{o}:$ 外気セスキテルペン濃度 $\left[\mu \mathrm{g} / \mathrm{m}^{3}\right]$ 


\section{$A:$ 杉板表面積 [ $\left.\mathrm{m}^{2}\right]$ \\ $G:$ 消失速度 $\left[h^{-1}\right]$ \\ $S E R:$ 杉板からのセスキテルペン放散速度 $\left[\mu \mathrm{g} / \mathrm{m}^{2} \cdot \mathrm{h}\right]$}

外気のセスキテルペン濃度を 0 とし、定常状態を想定すると、セ スキテルペンのオゾン反応による消失速度 G は以下のように計算さ れる。

$$
G=\frac{S E R \cdot A}{C \cdot V}-N
$$

式(3)によって計算した、ピーク番号 3,6,7 のセスキテルペンのオ ソン Low モード発生時とオゾン High モード発生時の消失速度 Gを 表 8 に示す。なお、各オソン発生モード時の室内セスキテルペン濃 度は、それぞれの期間に検出した濃度の平均值を用いた。表 8 をみ ると、ピーク番号 3 の Caryophyllene $<(\mathrm{E})$->の消失速度が、Low モー ド、High モードのどちらにおいても、他の 2 つのセスキテルペンに 比べ大きな值を示していることがわかる。換気による减衰速度すな わち換気回数は $0.6 \mathrm{~h}^{-1}$ であるが、Caryophyllene <(E)->は Low モード においても、換気回数の 5 倍以上の消失速度を示していた。これは、 Caryophyllene $<(\mathrm{E})->$ 端部に二重結合炭素原子をもつため、オゾン分解 がされやすいためと考えられる。

\section{表 8 ピーク番号 3, 6,7 のセスキテルペンの消失速度 $\left(\mathrm{h}^{-1}\right)$}

\begin{tabular}{|l||c|c|c|}
\hline オソン発生モード & $\operatorname{VOC}(3)$ & $\operatorname{VOC}(6)$ & $\operatorname{VOC}(7)$ \\
\hline \hline Low モード & 3.4 & 0.3 & 0.8 \\
\hline High モード & 8.2 & 2.1 & 3.5 \\
\hline
\end{tabular}

[ VOC(3) : Caryophyllene $<$ (E)->, $\operatorname{VOC}(6)$ : Muurolene $<$ alpha->, VOC(7): Cadinene $<$ delta- $>$ ]

本実験では、オゾンとの反応によって、どのような二次生成物が 生じているかは明らかにできなかった。実駼結果からも、オゾン発 生器によってオゾン濃度を上昇させ、セスキテルペン濃度が低减し た後に新しく生じた VOCや、濃度が上昇した VOC は明確でない。 Weschler \& Shield はテルペン VOC とオゾンとの反応により、高分子 量のアルデヒドやカルボン酸が生成され、それが微粒子濃度の上昇 に寄与することを報告している4)。微粒子濃度の測定も含み、今後、 二次生成物に関するさらなる考察・研究が必要である。

\section{5 まとめ}

機械換気された 2 つ室において、室 1 には、杉板を設置し、室 2 には設置しない状態で VOC 濃度を測定した。また、途中から強制的 にオゾンを発生させ、オゾン濃度を上昇させた状態で、VOC 濃度、 ホルムアルデヒド濃度等を測定した結果、以下の知見が得られた。

1）オソン濃度を上昇させるにつれ、セスキテルペン濃度は減少した が、ホルムアルデヒド、アセトアルデヒド、アセトンの濃度変化は みられなかった。オゾンがセスキテルペンと反応したことにより、 セスキテルペンの濃度が減少したことが推察されるが、その反応に よって、ホルムアルデヒド、アセトアルデヒド、アセトンの濃度が 上昇するという結果は得られなかった。

2）杉板から放たれるセスキテルペンのうち、大部分を占めていたも のは、Cadinene <delta->及び Muurolene <alpha->であった。これらの 二重結合炭素原子の位置及び化学構造から考察すると、オゾン分解
によってホルムアルデヒド、アセトアルデヒド、アセトンが生成さ れることは少ないと考えられる。

3） セスキテルペンの Caryophyllene <(E)->はオゾン分解により、ホ ルムアルデヒドを生成する可能性があるが、Caryophyllene $<(\mathrm{E})->$ 杉 板からの発生量が多くはないため、有意なホルムアルデヒド㳻度の 上昇には至らなかったのではないかと考えられる。

4）本実験では、オゾンとの反応によって、どのような二次生成物が 生じているかは明らかにできなかった。微粒子濃度の測定も含み、 今後、二次生成物に関するさらなる考察・研究が必要である。

【謝辞】セスキテルペンとオゾンの反态について、Charles Weschler， New Jersey 州立大学教授より多くの教示を受けた。なお本実験の実 施は、鹿児島大学学生の山口和敏氏の労によるところが大きい。本 研究の一部は、財団法人トステム建材産業振興財団研究助成「住宅 から発生する VOC とオソンの反応が室内空気質に及ぼす影響に関す る研究 (研究代表者 岩下剛)」による。

参考文献

1）厚生労働省シックハウス問題に関する検郡会中間報告書、厚生労働省ホー ムページ、http://www.mhlw.go.jp、2001

2) 柴原洋人、岩下剛、木造新筮住宅に扔けるテルペン類 VOC 浱度の経時变化、 日本建築学会大会学術講演梗概集、環境工学 II、pp.919-920、2002

3) Wolkoff, P., Clausen, P.A., Wilkins, C.K., and Nielsen, G.D., Formation of Strong Airway Irritants in Terpene/Ozone Mixtures, Indoor Air, Vol.10, pp.82-91, 2000 4) Weschler, C.J., and Shields, H.C., Indoor Ozone/Terpene Reactions as a Source of Indoor Particles, Atmospheric Environment, Vol.33, pp.2301-2312, 1999

5) Grosjean, D., Williams, E.L., Grosjean, E., Andino, J.M. and Seinfeld, J.H., Atmospheric Oxidation of Biogenic Hydrocarbons: Reaction of ozone with $\beta$-Pinene, D-Limonene and trans-Caryophyllene, Environ. Sci. Technol., Vol. 27, pp.2754-2758, 1993

6）黒木荘一郎、赤坂裕、岩下剛、小原聡司、兽我和弘、池田育郎、海江田貴 光、蒸暑地における断熱・気密住宅の温熱噮境と空気環境に関する研究（その 1 実験住宅の概要と基本性能)、日本建築学会大会学術講演梗概集、環境工 学 II 、pp.949-950、1996

7) Adams, R.P., Identification of Essential Oil Components by Gas Chromatography /Quadrupole Mass Spectroscopy, Allured Publishing Corporation, 2001

8）尾山秀平，岩下㓮、環境共生住宅の室内温熱空気噮境に関する実測調査、 日本建築学会大会学術講演梗概集、境工学 II、pp.913-914、2001 9) Ouellette、有機化学、化学同人、2002

10) Colombo, A., Bortoli, M.De., Knoppel, H., Schauenburg, and Vissers, H., Small Chamber Tests and Headspace Analysis of Volatile Organic Compounds Emitted from Household Products, Indoor Air, Vol.1, pp.13-21,1991 注

注 1）セスキテルペンはテルペンに属する化合物のうち炭素数 15 のものをい い、基本炭化水素およびその誘導体を総称するものである。

注 2) Kovats Index は Kovatsによって計算された、ある voCのピークの保持 時間と、それに近接するアルカンの保持時間から求められる指標》であり、各 VOC は固有の值をもつ。 